\title{
УДК 35:316.77
}

\section{MODERN TRENDS IN THE FORMATION OF THE CORPORATE COMMUNICATION SYSTEM IN PUBLIC AUTHORITIES СУЧАСНІ ТЕНДЕНЦІЇ ФОРМУВАННЯ СИСТЕМИ КОРПОРАТИВНИХ КОМУНІКАЦІЙ В ДЕРЖАВНИХ ОРГАНАХ}

Arkhypova Ye.O. / Архипова 6.O.

PhD in phil., as.prof. / к.рілос.н., дой. ORCID: 0000-0002-1640-1488

Hula M.S. / Гула М. master's student / магістрантка. National Technical University of Ukraine "Igor Sikorsky Kyiv Polytechnic Institute", Kyiv, Prosp. Peremohy, 37, 03056 Національний технічний університет «Київський політехнічний інститут ім. Ігоря Сікорського», Київ, пр-т Перемоги, 37, 03056

Анотація. В роботі розглянуто сучасні тендениї формування системи корпоративних комунікачій в органах публічної влади. Проаналізовано досвід використання в державноуправлінському секторі України та інших держав систем електронного документообігу та управління контентом (АСКОД, ДОК ПРОФ, FossDoc, ECM Alfresco, Government Transaction Portal). Визначено переваги, які надає державним органам використання вільного програмного забезпечення для управління контентом. Окреслено практику використання публічними органами інших комунікативних інструментів: корпоративних сайтів, сочіальних мереж, месенджерів.

Ключові слова: комунікація, державні органи, органи публічної влади, система електронного документообігу, управління контентом, сайт, месенджер

\section{Вступ.}

Ефективна та збалансована система внутрішніх і зовнішніх комунікацій $\epsilon$ однією 3 необхідних передумов якісного виконання своїх функцій організаціями усіх типів та форм власності. Комунікативна діяльність органів державної влади, яка забезпечується відповідною системою публічного менеджменту, полягає у здійсненні інформаційної взаємодії, спрямованої на виконання функцій публічного управління та адміністрування. Пошук, збір, опрацювання інформації, прийняття на іiі основі управлінських рішень, як i здійснення будь-яких управлінських впливів та взаємодій взагалі [1, с.11], забезпечується шляхом використання формальних комунікативних каналів, визначених на державному рівні або регламентованих на рівні органу публічної влади, а також через неформальні, неофіційні канали, наприклад різноманітні месенджери та соціальні мережі. Державні органи, так само як і приватні організації, потребують ефективної системи комунікації, яка дозволить раціонально використовувати наявні людські, фінансові та матеріальні ресурси $[1 ; 2]$.

\section{Основний текст}

Запровадження системи електронного документообігу та платформ, які дозволяють вирішувати задачі організації різноманітних інформаційних потоків у комплексі, є нагальною потребою організацій сучасного типу. Усунення застарілих методів обробки інформації та кореспонденції, оцифровування 
відомостей та даних, автоматизація процесів в державно-управлінській діяльності - це ключові завдання, які поставлені перед органами публічного управління в частині оптимізації комунікаційних процесів. Більше того, розвиток електронного документообігу та е-взаємодії є частиною Концепції розвитку електронного урядування в Україні, схваленої розпорядженням КМУ від 20.09.2017 № 649-p [3].

Ключову роль на рівні кожного окремого органу публічного управління відіграє система внутрішніх комунікацій. У роботі публічних органів розрізняють потоки вхідної документації (надходять від суб'єктів господарювання, громадян, інших органів державної влади і в подальшому скеровують до структурних підрозділів після резолюції керівника); вихідної (розроблені установою та надсилаються адресатам, що не входять до складу цього органу); внутрішньої (документи установи чи організації, які циркулюють виключно в їі межах). Кожна документальна одиниця рухається у власному потоці, розробляється i маршрутизується різними суб'єктами (користувачами). Спільна електронна платформа дає змогу (за наявності доступу та дозволу) відслідковувати рух документів та зв'язки, що встановлюються в рамках документообігу.

Система електронного документообігу покликана здійснювати централізоване управління документацією (оперативна заміна чи модифікація форми документу, контроль стану та термінів виконання тощо); маршрутизацію (автоматична передача документу на розгляд та візування); забезпечувати колективну роботу та розмежування прав доступу. Крім того, система електронного документообігу спроможна забезпечити інтеграцію із іншими електронними корпоративним системами, в тому числі бухгалтерськими, аналітичними та фінансовими [4, с.33-34]. Найпростіша система електронного документообігу в державно-управлінському секторі має бути адаптованою до специфіки роботи органу публічного управління та реалізовувати звичний алгоритм документообігу; підтримувати функції розсилки та візування; передбачати можливість зовнішнього контролю та бути придатною до інтегрування з іншими системами.

Розглянемо більш детально специфіку роботи із деякими системами електронного документообігу, які наразі застосовують органи публічного управління. 3 найбільш поширених виділяємо АСКОД (розробник ІнфоПлюс), ДОК ПРОФ 2.0 (СВIT Проф), OPTIMA-WorkFlow (Optima), Док Проф (Ситроникс), MasterDOC (Банкомзв'язок), Megapolis. Документообіг (Софтлайн).

АСКОД - це система електронного документообігу, яка завдяки своїм функціонально-технічним можливостям дозволяє нагромаджувати та систематизувати інформацію, що початково являється неструктурованою, підтримувати ділові процеси, котрі орієнтовані на роботу із документацією, та аналізувати відомості в частині документообігу [5].

Наразі зазначену систему експлуатує багато міських та районних рад, ДСНС, Державна архівна служба України, Український центр оцінювання якості освіти, Федерація профспілок України тощо. Основна перевага АСКОД 
зводиться до відсутності потреби у встановленні додаткового програмного забезпечення, а доступ до серверу здійснюється, як правило, через мережу Інтернет. Окрім цього, вона орієнтована на роботу через WEB-доступ, що $\epsilon$ актуальним для організацій 3 територіально-розподіленою організаційною структурою. Окрім електронного цифрового підпису, система передбачає можливість штрих-кодування документів, що суттєво мінімізує вплив «людського фактора» при обробці документації та зменшує навантаження на співробітників канцелярії.

3 практичної точки зору впровадження АСКОД доречно в тих органах державної влади, де левова частка роботи припадає на надання адміністративних послуг (відділи державної реєстрації актів цивільного стану, Державна служба України з безпеки на транспорті, Державна служба морського та річкового транспорту України, митна та податкова служби тощо). Це зумовлюється функціональними можливостями ідентифікації та обробки документів, що потрібні для надання адміністративних послуг: система визначає шаблон документу, вид послуги, перелік документації, яка необхідна для їі отримання.

За основу електронного документообігу в таких установах, як Державна регуляторна служба, Державна прикордонна служба, Міністерство охорони здоров’я, Національне агентство запобіганню корупції, Державна екологічна інспекція було обрану іншу платформу - ДОК ПРОФ 2.0. Реєстрація документації в системі, зазвичай, здійснюється шляхом проставляння штрихкоду у відповідності із номенклатурою справи. ДОК ПРОФ 2.0 дає змогу здійснювати контроль виконання, зокрема система здатна інформувати (нагадувати) про необхідність здійснення певної дії з документом за три дні до дедлайну. Програма передбачає підготовку документів у форматі Microsoft Word або OpenOffice.org iз застосуванням визначеного шаблону. На нашу думку, це формує не лише єдиний підхід до підготовки документації, але й дисциплінує виконавців, підвищує рівень їх корпоративної культури. Централізоване збереження документації відбувається у стислому форматі, а виконавці за потереби можуть залишити текстову копію документу на своїх ПК. Через систему можна надсилати пропозиції співвиконавцям, службові записки, залишати коментарі та зауваження.

Тестуючи дану систему ми відзначили грунтовно продуманий моніторинг процесів та формування статистичних звітів. Так, дозволяється відслідковувати, порівнювати чи узагальнювати дані в режимі реального часу. Окрім цього, розробник здійснив кілька вдалих технологічних рішень, що доречні і в роботі державних та муніципальних органів, а саме заповнення полів форми оптичним олівцем, графічну форму представлення даних, сканування складних документів.

Окремо зупинимося на системах електронного документообігу для тих державних установ, які працюють за принципом «єдиного вікна», тобто передбачають можливість централізованої подачі усього пакету необхідних документів для оформлення дозвільних документів одній посадовій особі. За таким принципом працюють, наприклад, центри надання адміністративних 
послуг (ЦНАПи). В комунікативних системах ЦНАПів циркулює значний обсяг документів та іншої інформації, що створюється та обробляється у процесі надання адміністративних послуг населенню чи юридичним особам, тому їх зручність та функціональність має надзвичайно важливе значення.

Багато ЦНАПів використовують систему FossDoc 3 модулем ЦНАП [6], який не лише спрямований на автоматизацію діловодства, але й функціонує як корпоративний портал. Переваги, які отримує ЦНАП у системі зовнішніх та внутрішніх комунікації із застосуванням даної системи, полягають, зокрема, у суттєвому скороченні часу при оформлення заявок від суб'єктів, котрі вже були попередньо зареєстровані в системі (користувалися послугами ЦНАП); можливості автоматично заповнення, здійснення пошуку та друку всіх необхідних форм; моментальній обробці заяв; здійсненні обліку повторних звернень громадян; наявності потужного багатокритеріального пошукового сервісу; обліку роботи реєстраторів, що допомагає об’єктивно оцінювати іï результати їх роботи.

Аналіз вітчизняних систем електронного документообігу дає змогу виділити їх особливість - відсутність вільного програмного забезпечення. Співставляючи їх iз закордонними програмними продуктами, відзначаємо цілком протилежну ситуацію: широке використання інформаційнокомунікативних платформ на базі відкритого вихідного коду.

Одним із таких рішень, впроваджених у органах публічного управління інших держав, є ECM Alfresco - програмне забезпечення для управління контентом організації. Воно дає змогу користувачам ефективно і оперативно управляти корпоративним інформаційним контентом. Широкі функціональні можливості передбачають підтримку електронного документообігу, можливість управляти проєктами, оптимізувати окремі державно-управлінські процеси, вести електронний архів, публікувати відомості в мережах, взаємодіяти як із колегами, так і зі спеціалістами інших органів публічної влади. Відкритий код, гнучкість, модульність платформи, широкий спектр інтеграцій та додаткових модулів дозволяють оптимізувати роботу платформи під запити і потреби конкретної організації. Відзначимо, що додаткові функції та підтримка у роботі iз програмою притаманні комерційній системі Alfresco Content Service (на відміну від безкоштовної версї̈ Alfresco Community Edition).

До числа користувачів цього програмного забезпечення належать Брістольська міська рада та поліція Хемпшира (Англія), департамент Жиронда, Спільнота Агломерації Монпельє та Бюджетна дирекція (Франція), Муніципалітет Керетаро (Мексика), уряд Нідерландів, Федеральна авіаційна адміністрація та Департамент охорони здоров’я Говарду (США), а також багато інших організацій публічної сфери по всьому світу [7].

Розглянемо детальніше специфіку застосування ECM Alfresco у зарубіжних органах публічної влади та державних організаціях. Так, комунікативну систему Alfresco використовує науково-дослідний центр NASA в Ленглі. Цей Центр надає послуги із структурного, аероакустичного та аеронавігаційного тестування, дослідні послуги для своїх департаментів, комерційних організацій та органів публічної влади. 
Прийнявши рішення про недоцільність подальшої експлуатації попередньої програми aeroCOMPASS через застарілу систему захисту інформації та складнощі, які виникали при роботі 3 новими форматами цифрової документації, NASA дослідило суттєву кількість цифрових платформ, що забезпечують як роботу із документацією, так і корпоративне спілкування, та зупинилися на програмі Alfresco . На їх думку, у порівнянні з аналогічними системами Alfresco мало ряд переваг, зокрема:

- відкритість та цифрова безпечність електронної системи для колективної роботи спеціалістів державної науково-дослідної організації;

- розширений функціонал, який зручно використовувати в колективній роботі;

- зрозуміла візуалізація, легка для сприйняття система налаштувань, відсутність суттєвих труднощів в усуненні технічних помилок;

- можливість перенесення усіх попередньо накопичених документів та сайтів у систему;

- наявність доступу до корпоративного контенту більше ніж 3000 працівників [7].

Американська асоціація страхових послуг, яка також належить до державних структур, активно користується у свої роботі контент-послугами, що надаються ECM Alfresco, і пакетом OpenContent Management Suite, що дає змогу покращити корпоративну роботу із формами полісів й іншими видами страхових документів. Система дозволяє Американській асоціації страхових послуг швидко реагувати на нормативні і законодавчі зміни. Інтеграція 3 Workshare Compare дозволяє динамічне внесення змін до документів.

Ще одним органом, який використовує Alfresco у своїй діяльності, $\epsilon$ Департамент охорони здоров'я округу Говард, Колумбія [7]. Як державна установа, він керується стандартами та нормами, які вимагають зберігати офіційні документи протягом багатьох років, а іноді довічно. Це призвело до того, що багато документів зберігалося поза межами Департаменту. Для того, щоб знайти певну інформацію, співробітники повинні були прийти у сховище та вручну шукати потрібний файл.

Співробітники Департаменту охорони здоров'я створювали документи локально або на спільних дисках, а положення безпеки на цих дисках не дозволяли іншим знаходити необхідні документи. Як результат, департаменти не могли самостійно обмінюватися даними або надавати доступ для спільної роботи із документами, не звертаючись за допомогою до IT-відділу.

Кілька років тому департамент почав шукати способи оцифрування всіх своїх даних. Потрібна була основа для створення документів, а також спосіб управління вже наявним масивом документів (в тому числі сканованими копіями), централізованому в одному місці. Агентству потрібно було гнучке, нестандартне рішення із наявними полями метаданих, для налаштування яких не було потрібно багато часу.

Оцінивши кілька рішень, агентство обрало ECM Alfresco як рішення для управління документами через відкриту архітектуру. Залучивши партнерські мікро-стратегіï Alfresco, вони також скористалося перевагами інтеграційного 
piшення Microsoft Office, яке поєднує простоту використання додатків Microsoft Office та потужність Alfresco, щоб забезпечити агентство необхідними інструментами для захисту конфіденційних документів.

Агентства транспорту, громадської інформації, політики охорони здоров'я та фіскальний департамент мали трохи пізніше також перейти на використання Alfresco. Наразі всі документи та електронні листи, передаються або створюються працівниками в межах Alfresco. Щомісяця створюється від 200 до 300 сторінок вмісту, які архівуються у Alfresco. Це важливе рішення для Говарду, яке використовується щоденно у відповідних адміністративноуправлінських процесах.

Ще один приклад - Брістольська міська рада у Великобританії, де впровадження в роботу системи Alfresco стало наслідком скорочення фінансування держустанови. Раціоналізація роботи в міській раді та функціонування Alfresco дало змогу автоматизувати опрацювання електронних документів; забезпечити обмін даними як на рівні міської ради, так із іншими органами публічної влади; модернізувати методику взаємодії з персоналом (в тому числі в умовах дистанційної роботи, що стало особливо корисним в умовах пандемії COVID-2019); поширити використання цифрової звітності.

В свою чергу, у Голландії більше двох десятків років функціонує єдина система для обміну електронною документацією - Government Transaction Portal, що забезпечує взаємодію працівників як в межах одного, так і з усіма органами публічного управління. Ця система має два інтерфейси: один доступний виключно для громадян та здебільшого стосується надання адміністративних послуг / консультацій / роз'яснень фізичними особами та бізнесу; інший - забезпечує корпоративну взаємодію уповноважених на здійснення державно-управлінських завдань членів колективу.

Що стосується використання комунікаційних мереж, які дозволяють взаємодіяти різним органам державної влади, то слід згадати National Computer Board, котра функціонує в Угорщині. Ще з 2008 року вона поєднує всі відділи, управління, відомства, які є структурними підрозділами Міністерства оборони та Міністерства внутрішніх справ. За допомогою цієї цифрової платформи в режимі on-line правоохоронні органи можуть швидко комунікувати між собою, 3 цивільними органами управління і системою охорони здоров'я.

Наведені приклади засвідчують переваги використання подібних рішень на основі вільного програмного забезпечення та доцільність їх впровадження в органах публічного управління та адміністрування в Україні.

Українськими державними організаціями також використовуються комунікаційні платформи змішаного типу, інтерфейс яких дозволяє обмінюватися інформацією як між різними територіальними відомствами чи підрозділами одного державного органу, так і здійснювати зовнішню комунікацію, представляючи певну інформацію у формі реєстру чи відкритих даних. До таких платформ відносять різні портали та сервіси, що знаходяться у розпорядженні окремих служб, зокрема, Інспекційний портал (державний нагляд та контроль в частині безпеки праці), електронна система Добровільної реєстрації українських громадян при подорожах за кордон («ДРУГ»), система 
«Лікар онлайн» тощо.

До переліку потужних елементів у системі державно-управлінських корпоративних комунікацій відносять і корпоративні соціальні мережі, які розглядаються як комунікативні засоби, діяльність яких забезпечується за рахунок мережі Інтернет. Корпоративні сайти зазвичай використовуються центральними органами влади i досить рідко - органами місцевого самоврядування. Для взаємодії вони частіше застосовують Facebook, так як він дозволяє створювати та вести персональні профілі, тематичні сторінки та групи, анонсувати певні заходи, коментувати події, публікувати результати. Майже кожне міністерство і більшість органів виконавчої влади мають сторінки у Facebook, у більшості також $€$ Twitter, чотири Міністерства публікують тематичні відео на YouTube.

Більш простою альтернативою корпоративних комунікацій є електронна пошта. У цьому контексті Google має значну кількість переваг, зокрема безкоштовність, здатність до інтеграції із іншими платформами, систематичне оновлення та україномовний інтерфейс. Корисними для налагодження зручного робочого середовища є вбудована система орфографічної перевірки, підтримка різних мов, фільтрація спаму та пошук відповідної кореспонденції за ії змістом. Наявність акаунту в Google дає змогу скористуватися іншими популярними додатками від Google (календар, карти, диск, чати, перекладач, форми та інші) та налагодити колективну роботу 3 документами, що $\epsilon$ важливим для публічного управління та адміністрування. Зокрема, гугл-форми активно використовуються для налагодження як внутрішніх, так $\mathrm{i}$ зовнішніх комунікацій, адже дають змогу проводити анкетування чи анонімне опитування для будь-якого кола осіб (співробітників чи серед зовнішньої аудиторії) швидко систематизувати та аналізувати інформацію.

Ще одним популярним інструментом, який використовується радше у неформальних комунікаціях, являються месенджери, зокрема, Viber, Telegram, WhatsApp, Skype, WeChat, Imo.im, Discord. Три перші платформи, які $\epsilon$ найбільш популярними, дозволяють формувати групи та окремі чати, долучати до вже існуючих груп інших членів колективу. Обмін, як правило, здійснюється у текстовому форматі, але передбачена можливість надсилання аудіоповідомлень та відеозаписів. Відмінність ділового спілкування у месенджерах від комунікацій в усному форматі чи через електронну пошту, зазвичай полягає в тому, що повідомлення носять фрагментарний характер. Схема корпоративного спілкування у месенджерах носить характер такої комунікативної техніки, як «мозковий штурм», що практикується в усному спілкуванні.

Прикладом платформ, що дозволяють реалізувати взаємодію фахівців публічного сектору, також можна назвати мобільні додатки, що, як правило, застосовують у соціальних сферах. Так, «FixMyStreet» - це проект англійського фонду «UK Citizens Online Democracy», що дає змогу громадянам повідомити місцеву владу про негаразди на дорогах (неякісне покриття, сміття, розбиті ліхтарі тощо), а останнім - передати фахівцям в роботу отримане повідомлення. Цей досвід згодом перейняла Канада, Німеччина та США. 
Розвантаження системи комунікацій в країнах ЄС та США здійснюється за рахунок роботи так званих «гонгів», які працюють при міністерствах та центральних органах виконавчої влади. За своєю організаційно-правовою формою «гонги» $\epsilon$ громадськими організаціями, котрі приналежні до державних установ, але в той же час - $\epsilon$ незалежними від політичного істеблішменту з точки зору підпорядкованості чи керівництва. Йдеться про Бюро консультації громадян у Великій Британії, Чехії, Польщі та Литві; Центр волонтерства у Данії (діє при міністерстві, яке опікується питаннями соціальної політики) тощо. Їх робота спрямована на надання оперативного консультування щодо заповнення різних форм, заявок, потрібних для отримання адміністративних послуг; вони взаємодіють із громадянами i тоді, коли останнім необхідна допомога у веденні переговорів; долучаються до врегулювання проблемних питань в сфері зайнятості та міграції. Іншими словами, діяльність цих бюро дає змогу скоротити час спілкування працівників публічного органу та громадянина за рахунок попередньої «підготовки» громадянина.

\section{Висновки}

В статті були розглянуті сучасні тенденції формування системи корпоративних комунікацій в органах публічної влади. Показано, що вітчизняні та зарубіжні органи публічного управління та адміністрування використовують різноманітні комунікативні інструменти. Окрім основних формальних комунікативних каналів, визначених нормативно-правовими актами або регламентованих на рівні конкретного органу публічної влади активно використовуються і неформальні інструменти комунікації.

Одним $з$ основних механізмів, який дозволяє налагодити та оптимізувати внутрішні інформаційні взаємодії є системи електронного документообігу. Відзначено, що комплексне програмне забезпечення на основі відкритого коду має значно ширші можливості для управління контентом організації завдяки модульності та можливості інтегрування додаткових програм, функцій i розширень.

\section{Література:}

1. Дрешпак В.М. Комунікації в публічному управлінні. Д.: ДРІДУ НАДУ, 2015. 168c.

2. Архипова Є.О., Дмитренко Н.О. Ефективна комунікація між органами державної влади та громадськістю як умова розвитку демократичного суспільства. Інвестииї̈: практика та досвід. 2016. №1. С. 92-96.

3. Концепція розвитку електронного урядування в Україні, схвалена розпорядженням Кабінету Міністрів України від 20.09.2017. № 649-p. URL: https://zakon.rada.gov.ua/laws/show/649-2017-p\#Text (дата звернення: 02.12.2020).

4. Бєльська Т. В. Документообіг в публічному управлінні. Харків. нац. ун-т міськ. госп-ва ім. О.М. Бекетова. Харків: ХНУМГ ім. О. М. Бекетова, 2019. 40 с.

5. Продукти АСКОД. URL: https://infoplus.ua/uk/page/products (дата звернення: 02.12.2020). 
6. Автоматизація ЦНАП та ВДР. URL: https://fossdoc.com/tsnap (дата звернення: 02.12.2020).

7. Alfresco: Customers Stories. URL: https://www.alfresco.com/customers (дата звернення: 02.12.2020).

\section{References}

1. Dreshpak V.M., 2015. Komunikatsiyi v publichnomu upravlinni [Communications in public administration]. Dnipropetrovsk: DRIDU NADU.

2. Arkhypova Ye. O. and Dmytrenko N.O., 2016, Effective communication between public authorities and the public as a condition of the development of a democratic society. Investytsiyi: praktyka ta dosvid, no.1, pp. 92-96.

3. The concept of e-government development in Ukraine, 2017. Available at: https://zakon.rada.gov.ua/laws/show/649-2017-p\#Text [Accessed 02.12.2020].

4. Belska T.V., 2019. Dokumentoobih v publichnomu upravlinni [Document circulation in public administration]. Kharkiv: KhNUMG.

5. ASKOD products, 2020. Available at: https://infoplus.ua/uk/page/products [Accessed 02.12.2020].

6. Automation of CNAP and VDR, 2020. Available at: https://fossdoc.com/tsnap [Accessed 02.12.2020].

7. Alfresco: Customers Stories, 2020. Available at: https://www.alfresco.com/customers [Accessed 02.12.2020].

\section{Abstract.}

Introduction. An efficient and balanced system of internal and external communications is one of the necessary prerequisites for the quality realization of its functions by the organizations of all types and forms. The aim of this paper is to consider the modern trends in the formation of the system of corporate communications in public authorities.

Main part. The experience of using of electronic document management system and content management systems in the public administration sector of Ukraine and other countries is analyzed. Emphasis is placed on the requirements for electronic document management systems for government agencies that operate on the principle of "single window". The advantages that the use of free enterprise content management software to state bodies are determined. It is noted that complex software based on open source has much more opportunities for content management of the organization due to the modularity and the ability to integrate additional programs, functions and extensions. The practice of using other communicative tools by public bodies is outlined: corporate sites, social networks, messengers.

Conclusion. It is shown that domestic and foreign public administration bodies use various communication tools. In addition to the main formal communication channels defined by regulations or regulated at the level of a particular public authority, informal communication tools are also actively used.

Keywords: communication, government bodies, public authorities, electronic document management system, content management, website, messenger. 